\title{
Principles and methodological approaches to efficient use of land
}

\author{
Natalia Ovchinnikova ${ }^{1 *}$, Natalia Aliyeva ${ }^{2}$, and Irina Petrova $^{2}$ \\ ${ }^{1}$ Don State Technical University, pl. Gagarina, 1, Rostov-on-Don, 344003, Russia \\ ${ }^{2}$ Novocherkassk engineering and reclamation institute named after A. K. Kortunov, Pushkinskaya \\ str., 111, Novocherkassk, 346400, Russia
}

\begin{abstract}
The use of commercial land, land parcels or land in general refers to an objectively complex process being one of the main components of land relations revealing their content. The principle of rational land use acquires its objective character on a basis of clear interaction between technical, technological, natural-biological, socio-economic and environmental components that ensure effectiveness of law of continuous recovery of soil fertility and productivity of agricultural lands. Land use is a process providing implementation of these properties which manifests itself as growth of production.
\end{abstract}

\section{Introduction}

Issues of improving the efficiency of land use with consideration of land resources environmental state are an integral part of the national ecological-economic policy that ensures the use, valuation, protection and management of land resources as well as the creation of data base on their natural, legal and economic status.

Creation of proper organizational, territorial, social, economic, environmental and legal conditions to ensure efficient land management, rights of landowners, land users and landowners, land plot functioning in civil circulation, soil conservation, protecting land from degradation, setting land rent and sustainable agricultural development will be a basis for improving land use efficiency.

Land should have a price that reflects its direct use value as well as other basic means of production in agriculture. There is a need to further improve a mechanism of land valuation and develop alternatives for effective calculation of land tax and land-use rent [1].

Land valuation factors can be used in a wide range of planning, economic and project activities. For this purpose, special methodological recommendations and programs are being developed in order to automate the process of finding solutions for specific tasks using the land valuation factors.

\footnotetext{
*Corresponding author: donong160875@yandex.ru
} 


\section{Materials and Methods}

The efficient use of land (plough land, perennial plantations, hayfields, pastures, irrigated hectares) can be assessed by the production yield per hectare of land area, capital-area ratio and energy availability per hectare of agricultural land and plough land, its production cost and income as well as by availability of fixed assets and energy capacities per employee of economic entity and return on resources [2].

Specialization and concentration of agricultural production in the Rostov Region has exercised a decisive influence on distribution and level of land use. In the process of land conversion, there have been structural changes, both in the composition of commercial land and forms of farming, in the composition of agricultural land (Table 1).

Table 1. Dynamics of commercial land in the Rostov Region, thousand ha. (as of 01.01.2020).

\begin{tabular}{|l|l|l|l|l|}
\hline \multirow{2}{*}{ Commercial Land } & \multicolumn{2}{c|}{ Total over Region } & \multicolumn{2}{c|}{ Including Irrigated Land } \\
\cline { 2 - 5 } & $\mathbf{2 0 0 0}$ & $\mathbf{2 0 2 0}$ & $\mathbf{2 0 0 0}$ & $\mathbf{2 0 2 0}$ \\
\hline Total area & 10.096 .7 & 10096.7 & 329.0 & 255.7 \\
\hline Plough land & 5923.3 & 5781.9 & 309.3 & 244.8 \\
\hline Perennial plantations & 39.9 & 63.0 & 10.6 & 6.0 \\
\hline Hayfields & 82.7 & 91.8 & 2.1 & 2.7 \\
\hline Pastures & 1834.8 & 2603.4 & 1.5 & 2.2 \\
\hline Total agricultural land & 7880.7 & 8540.1 & 323.5 & 255.7 \\
\hline Other land & 215.9 & 198.6 & 5.4 & - \\
\hline
\end{tabular}

According to the above data, the level of development of the Region's territory is quite high, where agricultural land covers the most area, namely, 8,540.1 thousand hectares or $84.6 \%$. Plough land covers $5,781.9$ thousand ha or $57.3 \%$ of the region's territory and $67.7 \%$ of the total area of agricultural land; $2,695.2$ thousand ha or $26.7 \%$ is accounted for natural forage land.

The land fund is distributed unevenly across agricultural zones of the region (Table 2). The largest in terms of land area are the North-West and East Agricultural Zones.

Table 2. Breakdown of land fund by agricultural zones in the Rostov region, thousand hectare (as of $01.01 .2020)$

\begin{tabular}{|l|l|l|l|l|l|l|l|}
\hline \multirow{2}{*}{ No } & \multirow{2}{*}{$\begin{array}{c}\text { Agricultur } \\
\text { al Zone }\end{array}$} & \multirow{2}{*}{$\begin{array}{c}\text { Total } \\
\text { Area }\end{array}$} & $\begin{array}{c}\text { Includin } \\
\mathbf{g} \\
\text { Agricul- } \\
\text { tural } \\
\text { Land }\end{array}$ & & \multicolumn{4}{|c|}{$\begin{array}{c}\text { Plough } \\
\text { Land }\end{array}$} & $\begin{array}{c}\text { Perennial } \\
\text { Plantations }\end{array}$ & $\begin{array}{c}\text { Hay- } \\
\text { fields }\end{array}$ & Pastures \\
\hline 1 & North-West & 2.348 .6 & 1.939 .8 & 1.263 .2 & 7.4 & 15.5 & 653.6 \\
\hline 2 & North-East & 1.772 .9 & 1.475 .8 & 1.053 .5 & 5.7 & 11.8 & 404.7 \\
\hline 3 & West & 1.433 .4 & 1.171 .9 & 927.1 & 16.7 & 20.9 & 207.2 \\
\hline 4 & Central & 968.9 & 789.4 & 561.2 & 9.6 & 23.5 & 195.1 \\
\hline 5 & South & 1.304 .6 & 1.175 .5 & 1.041 .9 & 7.7 & 2.7 & 123.2 \\
\hline 6 & East & 2.087 .6 & 1.914 .8 & 897.7 & 2.0 & 13.9 & 1.001 .2 \\
\hline & Total & 9.915 .7 & 8.467 .3 & 5.744 .6 & 49.2 & 88.3 & 2.585 .2 \\
\hline
\end{tabular}

Dynamics of land fund distribution over Central Irrigated Zone and by each administrative district are of great importance (Table 3). 
Table 3. Dynamics of Land Fund in Central Irrigated Zone, thousand hectares.

\begin{tabular}{|l|c|c|c|c|c|c|c|c|}
\hline \multirow{2}{*}{ Districts } & \multicolumn{4}{|c|}{1996} & \multicolumn{4}{c|}{2020} \\
\cline { 2 - 9 } & $\begin{array}{c}\text { Total } \\
\text { Area }\end{array}$ & $\begin{array}{c}\text { Total } \\
\text { Agri- } \\
\text { cultural } \\
\text { Land }\end{array}$ & $\begin{array}{c}\text { Incl. } \\
\text { Plough } \\
\text { Land }\end{array}$ & $\begin{array}{c}\text { Incl. } \\
\text { Irrigated } \\
\text { Land }\end{array}$ & $\begin{array}{c}\text { Total } \\
\text { Area }\end{array}$ & $\begin{array}{c}\text { Total } \\
\text { Agricu } \\
\text { Itural } \\
\text { Land }\end{array}$ & $\begin{array}{c}\text { Incl. } \\
\text { Plough } \\
\text { Land }\end{array}$ & $\begin{array}{c}\text { Incl. } \\
\text { Irrigated } \\
\text { Land }\end{array}$ \\
\hline Bagayevsky & 100.4 & 79.2 & 52.8 & 26.3 & 95.1 & 75.0 & 47.4 & 25.4 \\
\hline Veselovsky & 130.2 & 103.9 & 87.4 & 28.8 & 135.6 & 108.5 & 90.6 & 22.8 \\
\hline Volgodonskoy & 133.9 & 106.1 & 97.6 & 32.2 & 134.0 & 106.8 & 70.3 & 28.9 \\
\hline Martynovsky & 191.7 & 164.2 & 125.9 & 28.9 & 191.7 & 163.6 & 128.4 & 21.1 \\
\hline Proletarsky & 272.8 & 223.0 & 157.6 & 25.3 & 272.8 & 223.2 & 154.0 & 21.9 \\
\hline Semikarakorsky & 139.7 & 111.4 & 69.4 & 36.8 & 139.7 & 112.3 & 70.5 & 32.8 \\
\hline Total over Zone & 968.8 & 787.9 & 560.8 & 178.3 & 968.8 & 789.4 & 561.2 & 153.0 \\
\hline
\end{tabular}

From the above data, it can be seen that area of agricultural land and plough land has increased in this zone in general, but area of irrigated land has decreased by 25.3 thousand hectares indicating a decrease in the intensity of use of land resources in this region $[3,4]$.

\section{Results}

We propose general principles and specific methodological approaches for using land valuation data [5]. Practical application of these data is largely determined by a level of land diversity, that's why a diversity analysis becomes so important in solving various problems. Non-homogeneity of land quality is determined by indicators of technological properties and land fertility, as shown by the example of LLC "Belozernoye" in the Rostov Region (Table 4). In total, there are 110 working land plots for plough purposes allocated for evaluation of this farm.

Table 4. Land diversity by farm households in LLC "Belozernoye".

\begin{tabular}{|c|c|c|c|c|c|}
\hline \multirow[t]{2}{*}{ Land Valuation Factor } & \multicolumn{3}{|c|}{ Indicator Value } & \multicolumn{2}{|c|}{ Variation } \\
\hline & Minimum & Medium & Maximum & Range & $\%$ \\
\hline Soil bonitet, point & 26 & 55 & 79 & 53 & 22.4 \\
\hline Energy intensity, point & 100 & 114 & 125 & 25 & 8.2 \\
\hline Area elevation pattern, point & 86 & 99 & 100 & 14 & 3.2 \\
\hline $\begin{array}{c}\text { Profitableness of plough work, } \\
\text { point }\end{array}$ & 73 & 86 & 94 & 21 & 6.8 \\
\hline $\begin{array}{l}\text { Profitableness of non-plough } \\
\text { work, point }\end{array}$ & 86 & 98 & 99 & 13 & 2.9 \\
\hline Rockiness, coefficient & 1.00 & 1.00 & 1.00 & - & - \\
\hline Land topography, coefficient & 1.00 & 1.01 & 1.05 & 0.05 & 0.4 \\
\hline
\end{tabular}

Diverse quality of land plots causes differences in their yield. In the context of switching to a for-profit model, i.e. a collective form of labor organization and result-based 
remuneration, such differences in productivity and cost have an impact on production and finance activity.

The simplest method of assessing performance per entity is based on yield value of a point. For example, in relation to grain crops, soils of a farm are valued at 60 points. Over a given period ( 5 years), an average farm has produced $20 \mathrm{c} /$ ha, that is 0.33 centner per point. Such a yield per point, all other conditions being equal, should be obtained in all farm entities [6]. Thus, if with certain division the plough land is evaluated at 70 points, its estimated yield, taking into account soil quality, would be $23.1 \mathrm{c} / \mathrm{ha}(706 \times 0.33 \mathrm{c} / \mathrm{ha}=23.1$ $\mathrm{c} / \mathrm{ha})$.

Similarly, planned yield is differentiated by fields and plough land areas. When analyzing and planning yields per land plots or fields in production unit, the precursors, crop variety, fertilizer level and other factors are additionally should be taken into account according to their particular influence on yields [7] .

Estimated yield on irrigated land is to be calculated using area-based irrigation performance indicators (Table 5).

Table 5. Irrigation ratios for land-estimated areas of the Rostov region.

\begin{tabular}{|l|c|c|c|}
\hline \multirow{2}{*}{\multicolumn{1}{c|}{ Crop }} & \multicolumn{3}{c|}{ Estimated Area } \\
\cline { 2 - 4 } & I & II & III \\
\hline Grains, total & 1.3 & 1.4 & 1.6 \\
\hline Corn to grain & 1.3 & 1.6 & 1.6 \\
\hline Corn to silage & 1.4 & 1.7 & 2.2 \\
\hline Annual grass to hay & 1.8 & 2.0 & 2.2 \\
\hline Perennial grass to hay & 1.8 & 2.2 & 3.0 \\
\hline
\end{tabular}

An estimated actual or planned grass yield to hay is calculated considering quality of field or plot. If a plot of similar quality is irrigated, then estimated grass yield is increased by a factor of 2.2. Intra-farm cost standards for cultivation of crops by plot, field and plough land are calculated using estimated cost indicators by the following formula 1 :

where:

$$
C_{1}=\frac{C_{x} \cdot I_{0}}{I_{0 x}}
$$

$\mathrm{C}_{1}$ - Standard costs for crop cultivation in a particular production entity, mea. unit/ha;

$\mathrm{C}_{\mathrm{x}}$ - Planned level of costs on average per farm, mea. unit/ha;

$\mathrm{I}_{0}, \mathrm{I}_{\mathrm{ox}}$ - Indices of estimated costs, respectively, per particular entity and farm on average.

For example, on average for the farm, a planned level of costs for growing wheat is 120 $\mathrm{rub} / \mathrm{ha}$. In relation to grain crops, the farm's plough land is valued at 0.99 and a specific field - at 1.40, i.e. conditions for mechanization of operations on this field are worse. Consequently, with the same farm machinery cost of the field will be, according to the formula, 170 rubles/ha $(120 \times 1.40: 0.99=170)$. The labor and energy inputs for the production of other crops are similarly differentiated by intra-farm facilities.

\section{Discussion}

Indicators for assessing technological properties of land and productivity can be used by the farm for objective standardization of mechanized field work. For this purpose, working areas are evaluated on the basis of comparative productivity of ploughing, non-ploughing and harvesting operations [9]. Evaluation is carried out on the basis of coefficients of 
differentiation of aggregate production replacement ratios relative to reference conditions, where this coefficient is equal to 1.00. For this purpose, indicators are used to evaluate the profitableness of field mechanized work. Coefficient of production rate differentiation is calculated by dividing the points of the work profitableness by 100 . When determining the coefficient of work rates differentiation for non-ploughing operations, the working width of the machines should be taken into account $[10,11]$.

In the case of intra-farm field standardization, there are two options for differentiating the corresponding unit production rates.

The first option is based on differentiation of standard production norms in reference conditions according to the all-Union collection of standard norms. For example, the standard rate of products substitution when ploughing stubble fields with simultaneous harrowing by means of DT-75M tractor and P-5-35 plough with high-speed body under reference conditions (track length more than $1,000 \mathrm{~m}$, specific resistivity $0.50 \mathrm{kgf} / \mathrm{cm} 2$ ) is equal to 9.4 ha. In relation to plough operations, the field is rated at 75 points. Therefore, unit production replacement rate for this field will be 7.0 ha $(9.4 \times 75 / 100=7.0)$.

For the second option, it is recommended to differentiate the production rates used by the farm, which are average for the farm in terms of the conditions in which the work is carried out. The production rate for the plot is calculated by the following formula 2 :

where:

$$
R_{1}=\frac{R_{x} \cdot F_{1}}{F_{x}}
$$

$\mathrm{R}_{1}$ - Unit production rate per shift at a specific plot;

$\mathrm{R}_{\mathrm{x}}$ - Unit production rate on average for the farm;

$\mathrm{F}_{1}, \mathrm{~F}_{\mathrm{x}}$ - Assessment factor for respective land plot and farm's plough land as a whole.

If, for example, the farm's plough land has been evaluated in relation to plough work with a coefficient of 0.90 , and a norm of 8.8 ha set for the unit in question, then estimated shift rate for this area will be equal to $7.3 \mathrm{ha}$, as $8.8 \times 0.75=0.90=7.3$.

Evaluation of forage land allows us to reliably determine its forage reserve, calculate the optimal load of livestock per pasture area and farm as a whole. For example, a farm has 4,972 ha of pastures with a yield of 4.9 centners per ha ( 9.8 points) and 0.45 centner of protein/ha ( 9.0 points). The physical yield will be converted into conventional protein forage units (CPFU) by the following formula 3 :

where:

$$
C P F U=\frac{F+9 P}{2}
$$

$\mathrm{F}$ and $\mathrm{P}$ - Content of forage units and digestible protein in animal feed, respectively.

In our case, yield per hectare is 4.5 centners of CPFU and from the entire area of the farm pastures - 22,374 centners of CPFU (4,972 ha x 4.5 centners of CPFU / ha $=22,374)$. For annual maintenance of a conventional head of cattle, 41c of CPFU is required. Thus, the entire fodder reserve of pastures allows keeping 546 conventional head of cattle during the year, and 996 conventional heads during the pasture period (200 days).

If any farm has hayfields, then its forage reserves should be combined with pasture. If the amount of feedstuff is not sufficient for the existing livestock, the lack of forage shall be grown on plough land. Optimal load of livestock on pasture areas should be calculated in a similar way $[12,13]$.

The results of economic efficiency assessment of land plots can help to address a number of practical issues in the economy. For example, some farms currently divide their land into shares or establish peasant farms. All these land plots should provide an equal income to their owner, which depends primarily on quality of land and distance (all other 
things being equal) $[14,15]$. These factors will be summed up in cost recovery (RUB/RUB). For example, in a farm the cost recovery of plough land for grain comprises 4.54 RUB/RUB, and for individual calculated plots - $3.63 \mathrm{RUB} / \mathrm{RUB}$, respectively, and $5.50 \mathrm{RUB} / \mathrm{RUB}$ in average 10 ha of plough land per employee. Taking into account soil fertility and distance, to obtain equal income in the first case, it is necessary to allocate 8 ha and in the second case - 12.1 .

The analysis of land use has demonstrated that reduction of land area is mainly due to the following:

Reorganization of former collective and state farms and establishment of various economic entities on their basis;

Lack of funding for repair and reconstruction of irrigation network;

Introduction of payment for the use of irrigation water, which new economic operators cannot afford;

Decrease in purchase prices for manufactured products and, on this basis, a decline in the interest of citizens in irrigated farming;

Actually, termination of work on the design and creation of new irrigation systems.

As a result of carried out land reforms, monopolistic state ownership of land has been abolished and on its basis private and collective forms of land ownership has emerged. In turn, state ownership of land is realized through federal, municipal property and property of members of the Russian Federation. In this regard, the following types of land ownership have developed in the studied context (Table 6).

Table 6. Breakdown of land in administrative districts of the Central Irrigated Zone by all types and forms of land ownership.

\begin{tabular}{|l|c|c|c|c|}
\hline \multirow{2}{*}{ Districts } & \multirow{2}{*}{$\begin{array}{c}\text { Total } \\
\text { Area }\end{array}$} & & \multicolumn{3}{|c|}{ Including } \\
\cline { 3 - 5 } & & $\begin{array}{c}\text { Owned } \\
\text { by citizens }\end{array}$ & $\begin{array}{c}\text { Collectively } \\
\text { owned by legal } \\
\text { entities }\end{array}$ & State-owned \\
\hline Bagayevsky & 95.1 & 66.0 & - & 29.1 \\
\hline Veselovsky & 135.5 & 81.1 & 1.6 & 52.8 \\
\hline Volgodonskoy & 134.0 & 71.4 & 7.9 & 54.7 \\
\hline Martynovsky & 191.7 & 139.3 & - & 52.4 \\
\hline Proletarsky & 272.8 & 128.8 & 5.8 & 138.2 \\
\hline Semikarakorsky & 139.7 & 62.7 & - & 77.0 \\
\hline Total over area & 968.8 & 549.3 & 15.3 & 404.2 \\
\hline Total over region & $10,096.7$ & 64.8 & 142.5 & $3,536.1$ \\
\hline
\end{tabular}

As can be seen from the above data, about $64 \%$ of all land in the region has been transferred to citizens in the form of land shares, which in the long term should provide a significant increase in the intensity of use of valuable agricultural land.

\section{Conclusions}

Therefore, in each case when allocating land resources, land estimates shall be used.

In this regard, determining criteria for land use efficiency and development of an approach for rational land use, methods of control and planning of land use in the conditions of a transforming agrarian economy are of particular importance. It is critical to establish effective mechanisms in part of substantiation of organization of rational use of land resources taking into account ecological and economic factors and methods of estimation and management of land resources under the conditions of emerging land market. 


\section{References}

1. Immovable Property Cadastre, Cadastral activity in Russia: Experience of the present and prospects of the future, The 6th All-Russian Congress of Cadastral Engineers (SRO «Cadastral Engineers», Moscow, 2017)

2. M. Ogryzek, R.Wisniewski, T.Kauko, Real Estate Management and Valuation, 26(3) (2018) https://doi.org/10.2478/remav-2018-0022

3. N. Ovchinnikova, D. Burdova, M. Garanova, E3S Web of Conferences, 91 (2019) https://doi.org/10.1051/e3sconf/20199108023

4. T.S. Wilson, B.M. Sleeter, R.R. Sleeter, et al., Land, 3(2) (2014) https://doi.org/10.3390/land3020362

5. J. Wójcik-Leńa, K. Sobolewska Mikulska, N. Sajnóg, P. Leń, Land Use Policy, 78 (2018), https://doi.org/10.1016/j.landusepol.2018.06.044

6. W. Han, X. Zhang, X. Zheng, Land Use Policy, 92 (2020) https://doi.org/10.1016/j.landusepol.2019.104432

7. N.G. Ovchinnikova, MATEC Web of Conferences 10.1051/matecconf/201710601004

8. N.G. Ovchinnikova, Terra economicus, 7(2)-Cl.2, 41-44 (2009)

9. V.A. Chudovska, Balanced Nature Using, Institute of agroecology and environmental management, 7(4) (2016)

10. S.Lai, F. Leone, C. Zoppi, Sustainability, 9 (12) (2017) https://doi.org/10.3390/su9122174

11. S.G.Sheina,.A.Khamavova, Procedia Engineering, 150 (2016) https://doi.org/10.1016/j.proeng.2016.07.198

12. O. Mertz, C. Filt Mertens, World Development, 98 (2017) https://doi.org/10.1016/j.worlddev.2017.05.002

13. M. Lengoiboni, C. Richter, Jaap Zevenbergen, Land Use Policy, 85 (2019) https://doi.org/10.1016/j.landusepol.2019.03.023

14. B. Gilbey, J. Davies, G. Metternicht, C. Magero, Environmental Science \& Policy, 100 (2019) https://doi.org/10.1016/j.envsci.2019.04.007

15. D. Smiraglia, T. Ceccarelli, S. Bajocco, L. Salvati, L. Perini, Environmental Research, 147 (2016) https://doi.org/10.1016/j.envres.2015.11.030 